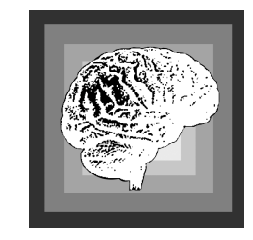

\title{
French psychiatry and the new woman: the case of Dr Constance Pascal, 1877-1937
}

\author{
FELICIA GORDON* \\ Anglia Ruskin University, Cambridge
}

This article traces the connections between the public career and private life of Constance Pascal (1877-1937), the first woman psychiatrist in France, in the social context of the Belle Époque. Pascal, of Romanian origin, attained professional success at the cost of suppressing her personal life. Best known for her work on dementia praecox, she researched the social as well as the biological causes of mental illness. She founded one of the first 'medical-pedagogic' institutes in France. Her monograph, Chagrins d'amour et psychoses (1935) reflects her wide cultural interests. Until recently, Pascal has been neglected by historians of psychiatry and of French women's history. Her life exemplified many of the conflicts experienced by women entering hitherto allmale professions.

Keywords: feminism; France; history; Pascal; psychiatry; social history

\section{Introduction}

Where, as an historical subject, should one place Constance Pascal, the first woman in France to become a clinical psychiatrist? A pioneer in women's professional achievements, her psychiatric writing has recently been the subject of renewed interest (Barbier, 1997; Barbier, Serra and Loas, 1999; Chazaud, 2001; Rees, 2001). Her extensive publications range from an authoritative study of dementia praecox (Pascal, 1911a), through experiments with shock therapy (Pascal and Davesne, 1926), to a more psychoanalytic approach (Pascal, 1935). Her public career, spanning twenty-nine years in a series of large asylums, has been documented (Barbier, 1997). However, there has hitherto been a paucity of information on her private life. ${ }^{1}$ Newly available sources from family papers (PRFP) have now made it possible to

\footnotetext{
* Address for correspondence: 1 Latham Close, Cambridge CB2 2EL, UK. Email: fmgordon@ globalnet.co.uk
} 
rectify this situation. Pascal's position in psychiatry required a disciplined public persona and, as a woman 'first', an impeccable moral character as that was understood in Third Republic France. In this article I will focus on how the rigorous separation Pascal maintained between her public and private lives illuminates the social history of women entering previously all-male professions. In addition, I will argue that the tensions she experienced between the public and the private found creative expression in her psychiatric work and writing.

Pascal lived a number of different and sometimes conflicting roles: as a Romanian immigrant ${ }^{2}$ in a still xenophobic France; as one of the new breed of dedicated professional women; as a clinical psychiatrist; as a researcher in mental illness; and, in her domestic life, as a single mother and educator of her only daughter. To maintain the secrecy surrounding the origins of Jeanne Pascal, her biological daughter whom she adopted, Constance Pascal built a wall of reserve between herself and her professional colleagues. The life of this intensely private family was not, I suggest, idiosyncratic, but symptomatic of the cultural constraints facing women in early twentieth-century France who sought to distinguish themselves in the professions.

The disjunctions between Pascal's professional and private life emerge in any character sketch that one attempts. Contemporary observers speak of her authoritative presence and dignity. She was highly intelligent, proud and, as a young woman, very beautiful. She was superbly well educated in the arts and humanities as well as the sciences. She spoke at least five languages. She had enormous charm, when she chose to exercise it, but did not suffer fools gladly. Her political sympathies were broadly on the left. She was strongly anti-clerical. She was a feminist 'through action, not by public agitation', in the words of her friend, Mathilde Salomon, Director of the Collège Sévigné. ${ }^{3}$ She possessed a keen sense of irony. She derived great joy and pride from the educational progress of her daughter, Jeanne. She read widely in history, literature and philosophy. She was an intellectual elitist, who worked all her professional life with society's most marginalized individuals. Internally she was wracked by anger, loneliness and guilt.

\section{Family background and education}

Pascal's father, Ion Pascal, a traditionally-minded member of the Romanian landed gentry, had opposed his daughter's educational ambitions. Years later she recalled how her brother Trajan was encouraged to study and to pursue a military career, whereas she, Constance, 'thirsty for knowledge', was expected only to cultivate her personal attractions. She inveighed against the upbringing of girls of good family in Romania:

What are parents' duties towards their daughters? Why do they allow them to study no further than primary school? They are fattened up until 
their marriage, without being reproached for the food they eat. They are dressed like dolls to go to balls and hunt husbands, without being reproached for the money spent on clothes and the cost of attending functions. They are married off, given a dowry without being reproached and their parents are happy to give their daughters their money. My great fault was to have wanted to study. In my unenlightened family, my education has been considered a useless and costly ornament. ${ }^{4}$

Pascal's profound sense of anger and injustice concerning her treatment in relation to her more fortunate brother never left her. In later life she broke completely with her Romanian connections. Reflecting ruefully on her 'family romance', she remarked: 'Decidedly the family, or family feeling is very complicated and I can understand my mad patients who lose it altogether. ${ }^{5}$

Her father's death in 1891 freed Pascal to continue her education. In 1897 her family agreed to make her an allowance to pursue her medical studies in Paris. Like many of her class in Romania, Pascal had received a thoroughly Francophone and Francophile education, imbibing Enlightenment culture, though living in a still feudal society. France had become a Mecca of opportunity for ambitious young women, by opening its medical faculties to women students in $1868 .{ }^{6}$ The fact that French women, prisoners of domestic ideology, rarely took advantage of this opening meant that, in the medical faculty, foreign women far outnumbered the French for many years. ${ }^{7}$

To women from Eastern Europe, France must have seemed like a paradise of female liberation and intellectual opportunity. For them French cultural norms and male anxieties about gender were mild in relation to the still rigid class and gender structures of their own countries. Fortunately for foreigners perhaps, through French eyes, they could be viewed as exceptions to the rule of obligatory femininity and domesticity. Still, whether French or foreign, women entering higher education and the professions assumed a symbolic importance out of all proportion to their statistical numbers. These women saw themselves and were seen, as role models, whether pioneers or rebels.

As a medical student at the turn of the century, Constance Pascal fitted the paradigm of the 'new woman' by virtue of her remarkable spirit of independence and her ambition, although it is doubtful whether she would have accepted that description for herself. Whereas the new woman of the Belle Époque was popularly seen as flouting convention in her love life, profession, dress sense or sporting ambitions (much was made of the liberating effects of the bicycle), many talented women took care to avoid a flamboyant life-style, or indeed to rock the boat, in relation to gender roles (Roberts, 1994, 2002). Professions such as teaching, medicine, law and psychiatry demanded of women, far more than of men, discipline, dedication and especially social decorum. In state-funded services like education and psychiatry, the advantages of secure conditions of service (automatic promotion, statutory sick leave, annual holidays, pension rights) were often tempered by a sense of marginality and social isolation, well documented in the lives of 
'institutrices' and women lycée teachers (Margadant, 1990: 4). In her first psychiatric posting, Pascal would discover how debilitating this isolation or exceptionalism could become.

If they were not overt rebels, these exceptional women nevertheless saw themselves as feminist innovators by opening their professions to others and by serving as role models for subsequent generations. Pascal's perception of this role emerges clearly in an article she wrote in her mid-fifties on the competitive examination for asylum doctors (le concours du médicat) of 1933:

\begin{abstract}
Three women swept to victory and I hope fame. Three more women civil servants [asylum doctors formed part of the civil service] in present-day society. It is an unbeaten record by feminism in the concours du médicat. In that far-off period when I presented myself for the examination [1908], the question of whether women had souls or not was still being discussed. In this last examination, the only dispute was on the quality of the examination answers, and I had the strong conviction that if all my colleagues are not feminists; they were in no way hostile towards the candidates. The professional question that arose, one useful for women, is the following: can a woman manage a male [psychiatric] ward? Now, I began my career at Clermont in a male ward, then I ran another male ward at Prémontré and at Châlons. At Moisselles, where I was a director, I had men working under my orders. I never had a problem with maintaining authority. ${ }^{8}$
\end{abstract}

This is an almost direct refutation of the arguments of Dr Edouard Toulouse who, though a supporter of women's rights, had argued that women asylum doctors would lack authority with male patients and male staff. ${ }^{9}$ Toulouse, generally a liberal on gender issues, was not one of those who wondered whether women have souls, but he saw the subversive significance of granting women administrative and professional authority in one of the major public institutions of the Third Republic, the psychiatric service.

Pascal said that she entered psychiatry because the limited income from her Romanian family was insufficient to launch her medical career. 'I left the hospitals [of general medicine] because in order to be an intern in general medicine one must be rich. One is not paid. In the asylums, I had enough to live on. ${ }^{10}$ She passed the internat examination in 1903 and the concours for médecin-adjoint des asiles in $1908 .{ }^{11}$ Psychiatry also attracted Pascal as an intellectual challenge and one in which she hoped to reform the often-punitive treatment of patients. What moved people from normal to abnormal states of mind? She wrote: 'We know that the mad person is a passionate being, every day revealing to us a world of facts that sharpens our curiosity. I have remained fascinated by all the mysteries of their thoughts. ${ }^{12}$ Her choice of profession, then, was a safe economic option, a compassionate response to suffering and a possible route to unravelling the complexities of the mind. What was never in doubt was that she was determined to escape the stultifying life of the Romanian gentry and to succeed in a professional career. 


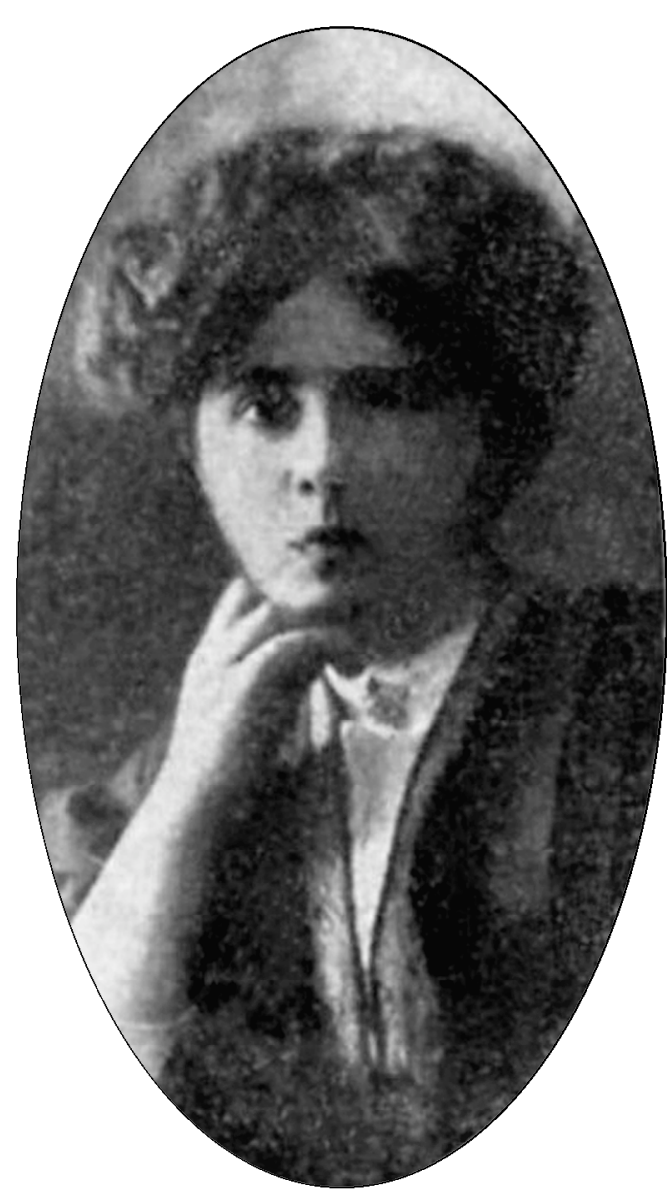

FIG. 1. Constance Pascal as a young woman, c. 1905

(source: La Vie heureuse, 1905)

\section{Feminism}

How did Pascal see her position in relation to the developing French feminist movement, forefronted in psychiatry by her colleague, Madeleine Pelletier? These two ambitious women, contemporaries, both interns in psychiatry at Ville Evrard, illustrate diametrically differing approaches to advancing the cause of women. Pelletier, who grew up in great poverty in Paris, stressed her working-class roots as well as her feminist convictions. It was Pelletier who in 1902-3, with the help of the feminist paper, $L a$ Fronde, orchestrated the campaign to give women access to the examination for psychiatric internships. Pascal did not take part in this very public campaign, almost certainly from motives of prudence arising from her foreign status. ${ }^{13}$ However, both she and Madeleine Pelletier trained at Ville Evrard in the eastern suburbs of Paris at the same period. It is difficult to imagine two more contrasting types. Madeleine Pelletier, short and pugnacious, advertised her feminist convictions by wearing tailored 'mannish' suits and cutting her hair short. Constance Pascal, by contrast, tall and elegant, with a magnificent mane of beautifully arranged black hair (Fig. 1), combined charm, decorum and aristocratic authority.

Pascal's triumphant success on her doctoral thesis was lauded in the press as both a feminine and a feminist success. Her dissertation Formes atypiques de la paralysie générale: prédominance régionales des lésions dans les méningoencéphalites diffuses (1905), gained the full approval of the jury, which included professors Roger, Brisaud, Gaucher and Carnot. They awarded her a 'Très bien', the highest mark:

Feminism can be proud of this new success, especially as Mlle Pascal, while devoting herself to science, has succeeded in retaining the exquisite 
charms of womanhood. The audience who attended the 7 June defence of her thesis did not know which to admire more, the ease with which she dealt with the most difficult questions of mental medicine or the tact and feminine wit which guided her answers. ${ }^{14}$

A contemporary male intern at the Asylum of Ville Evrard, remembered Pascal and Pelletier in a passage equally redolent of the gender expectations of the Belle Époque:

I should mention the feminine phalanx that occupies today an evergreater place in our ranks. I will only speak of those who were the first and with whom I lived in the staff room: Constanza Pascal and Madeleine Pelletier, who were in the first wave of women interns. Constanza Pascal, born a Romanian and naturalized French, then in all the glory of her youth, merited the double epithet that the historian of the Middle Ages gave to one of her predecessors, a professor at the [medical] school of Salerno: Constanza Calenda, as beautiful as she was learned. Madeleine Pelletier was born in Paris; obsessed by her theory of the absolute equality of the sexes, she would have rejected as an insult the first of these epithets [beauty]; she endeavoured, by her dress and her manners, to let no one have the idea of applying it to her. She became notorious in the suffragette period. I don't know what happened to her. ${ }^{15}$

It is not hard to imagine that Pelletier would have bridled at Pascal's elegance and class assurance and that Pascal would have found Pelletier's touchiness and feminist militancy rebarbative.

Did Pascal consider herself to be a feminist? A feminist commitment may seem unlikely, given her lack of militancy in feminist groups and the journalistic pæans to her femininity. Such a view is certainly mistaken (Gordon, 1990: 70-1; Sowerwine, 1988). Pascal retained a visceral sense of women's inferior status. She held fiercely to the dignity conferred on her by her abilities and her professional status. She fought for the improvement of nurses' training and conditions of service in the hospitals where she worked. She was proud to have been the first woman to serve as an expert medical/ psychiatric witness on courts martial dealing with shell-shock victims; she welcomed during her lifetime the growing number of women seeking psychiatric posts, and she brought up her daughter to be intellectually and financially independent. As we saw in her career summary above, she did not claim to suffer discrimination in her professional life. Yet in her conflicts with the hospital administration, and particularly in her perceived need to conceal her personal life, she experienced what were in reality the effects of social inequality relating to women.

\section{Early career and publications}

Following Pascal's career path through a series of hospitals and her research record, in parallel with her complex private life, we can appreciate the efforts 
she undertook to maintain her confident and authoritative public persona as well as her privacy. Her first two psychiatric posts at Clermont de l'Oise (1908-17) and Prémontré (1920-22), both in Picardy, coincided with the war and post-war traumas of a ravaged country. The Asylum of Clermont, fairly typical of the large and overcrowded psychiatric hospitals of the period (Foucault, 1961; Goldstein, 1987; Porter, 2002; Scull, 1979), was in a provincial backwater. Seriously understaffed when Pascal arrived there, the hospital had 140 nurses for 1673 patients. Hygiene was abysmal; typhoid and tuberculosis were common. The large number of the criminally insane sent to the hospital had resulted in its being turned increasingly into a prison. In the words of a former director (quoted in Teillet, 1983: 24):

When one enters this asylum ... one gains a sinister impression. Asylums should be cheerful and give the idea of tranquillity where the patient, whoever he be, comes to recuperate and to rest after a breakdown, or mental fatigue, which has destroyed his reason. This asylum gives the impression of a penal colony.

Pascal was soon forced to abandon whatever hopes she might have had to reform asylum practice. She felt herself to be only a cog in a huge institution and, being obliged to live in the asylum grounds, subject to almost as much surveillance as the patients:

One would need a volume to describe the organization of the Clermont Asylum. Someone has written a book, called The Penal Colony for the Mad which indicates how excellent the organization is. That was seven or eight years ago. But now it is the Penal Colony for Psychiatrists. ${ }^{16}$

However, a newspaper article of the same period (c.1912) described Pascal in glowing, almost Florence Nightingale terms, painting a much more positive picture. The reporter eulogized her for the reforms she had introduced and for her soothing, feminine qualities:

This woman, the only one to have successfully passed the examination for doctors in mental hospitals, has lived for the past three years devoted to the most thankless of tasks, in this solitude, in the midst of a population of degenerates and the demented to whom her care brings a little relief and her presence a bit of joy. For Mlle Pascal is young and beautiful and when she passes through the wards, gloved and her hair beautifully arranged, with an authoritative gesture and look, the most agitated patient pulls himself together for a moment in her presence and asserts his weak powers of inhibition remaining to him, to restrain his furies and his foul language. All these unfortunates felt in some sense that underlying the doctor's medical wisdom was a woman's pity and, without always understanding, thanked her for her goodness. One of them, an epileptic said to me: 'Ah, if she were not here, what would become of us?' Mlle Pascal has forbidden punishments and has abolished strait-jackets. ${ }^{17}$ 
Pascal's first years at the hospital appear to have been fruitful, both in psychiatric practice and in research. She published a series of clinical studies of dementia praecox (Pascal, 1906a, 1906b, 1906c, 1906d, 1907a, 1907b, $1907 c, 1908,1911 a$ ). These culminated in her monograph, La Démence précoce (Pascal, 1911b). Though dementia praecox would be superseded as a diagnostic concept by schizophrenia in the succeeding decades (Bleuler, 1911), Pascal's monograph remained a reference text on the subject in France into the 1950s (Barbier, 1997: 77). ${ }^{18}$

Pascal had made dementia praecox her principal subject, under the influence of her supervisor at Ville Evrard, Dr Paul Sérieux, an enthusiast for the work of the German psychiatrist Emil Kraepelin (1856-1926). Although it is sometimes claimed that the French scientific climate could be hostile to German ideas (Morel, in Barbier, 1997: 76), Pascal actively engaged with German psychiatric research. For example, she read Jung and Freud at least a decade before they were translated into French, or were widely made known to a French public. ${ }^{19}$ Pascal praised the key role that Kraepelin, whom she evidently admired and with whom she had corresponded, had played in identifying dementia praecox as a syndrome. ${ }^{20}$

La Démence précoce dealt with the history, nosology, symptoms, characteristic mental weaknesses, development, organic basis, possible causal factors, pathology, diagnosis, relevance to legal medicine and (briefly) treatment of the disease. Pascal (1911b: 304-5) ${ }^{21}$ noted especially its effect on the young:

The frequent appearance of dementia praecox during the student years (childhood, puberty, adolescence) leads educators into many errors. Most of these young patients are confused with abnormal children, or considered to be vicious, badly behaved, lazy, stubborn, etc., and become the recipients of punishments and disciplinary sanctions. Often dementia praecox attacks brilliant pupils, who are the pride of their parents. After having shown an intellect full of promise, they learn nothing more; they become incapable of evolving, of acquiring new knowledge and of submitting to regular labour.

Although focusing principally on diagnostic signs, Pascal also traced the social dimension of the disease. A concern with juvenile delinquency and the treatment of children and adolescents in prisons and psychiatric hospitals marked her subsequent career.

In a rather different context, Pascal's 1908 article on the composer Schumann provides evidence of her cultural interests. Like Maupassant, Van Gogh, Dostoevsky and a host of other nineteenth-century artists, Schumann's mental afflictions have received a great deal of scrutiny from historians, as well as from psychiatrists (Basch, 1928/1936; Ostwald, 1985; Stricker, 1984; Taylor, 1982). Pascal's choice of title, with its plural ('The mental illnesses of Robert Schumann'), contributed to the still unresolved debate about Schumann's madness, expanding Pascal's previously developed thesis (Pascal, 
1906c) of the possibility of distinct mental illnesses existing in an individual over time.

The central cultural question that drew Pascal to Schumann concerned the relation between genius and madness: 'His whole life was nothing but a battle to the death, without respite and without a truce between two powers, that of expanding genius affirming and defending itself and that of his illness which devoured little by little his body and soul' (Pascal, 1908: 99).

Was this the genius of madness, or genius responding with insight to periodic mental instability? Pascal argued that from the ages of twenty-one to forty-one Schumann suffered from a constitutional illness, physical in origin and probably hereditary but not from general paralysis, nor dementia praecox. From forty-one onwards, he fell victim to a different illness, which took a progressive and fatal form. The earlier neurosis and the later disorder were, she believed, separate phenomena. It was the concept of genius itself and whether it was not only allied to, but even a product of, madness that most intrigued Pascal. She rejected the Romantic concept of the sick soul as the basis of great art. Describing Schumann's final collapse, after he had been obliged to resign his post as conductor at Dusseldorf, she evoked Nietzsche:

For the mind as for the body, to abandon work is to begin to die. This genius of sound put out its torch. A terrible illness, which pardons no one [this would probably have been the onset of terminal, tertiary syphilis (Quétel, 1992: 139-75)], robbed him progressively of all his faculties: his will, his intelligence, his exquisite sensibility, and the fecund source of so many beautiful artistic creations. He disappeared like Nietzsche's superman 'at the moment when he had attained the highest degree of wisdom, at the moment where the sun of his existence was at its zenith, at the hour of noon, consecrating by his death the triumph of his doctrine.' (Pascal, 1908: 113)

We find in Pascal's 1914-18 war journal (PRFP) frequent references to superior minds battling mediocrity. She read Schumann's illness as paradigmatic of those gifted individuals whose nervous constitutions could destroy them, a fate she may have feared for herself. She sought to establish the sanity of genius, to demonstrate that through the power of art, genius could escape from the prison of mental torment. Implicitly she aligned herself with Nietzsche's exceptional individuals.

\section{War and love}

In 1914 Pascal's reforming agenda at Clermont came to a standstill. She had hoped to create asylum schools, outpatient psychiatric services and family colonies for the less severely afflicted patients. All these plans were halted by the outbreak of World War I. Clermont was briefly occupied by the Germans 
in 1914 and thereafter was never far from the front line. Unlike Prémontré which lay within German-occupied France for the duration of the war, the patients were not evacuated, but conditions for all civilians were harsh (Becker, 1998; Blancpain, 1983; Gaines, 1918; Macintyre, 2001; McPhail, 1999). To live in this region during the war years was to experience first hand 'the irreparable and incomprehensible catastrophe' of the German invasion (Duroselle, 1995: 436) The vulnerability of the asylum population, condemned to food and fuel shortages and terrible hygienic conditions, was a daily reproach to medical staff. According to Pascal, the director, a vain and dictatorial individual, neglected his patients: 'The dormitories are dirty, mattresses and blankets need changing, there are lice in the beds - flies and mosquitoes everywhere'. The staff were cowed: 'It is comic to see these terrorized beings before a little, vulgar, choleric, impulsive, violent man. ${ }^{22}$ Pascal's journal records the continual boom of cannon, the sound of artillery fire, patients' complaints about food shortages, the loss of asylum staff to the war and reception of shell-shocked soldiers at the hospital. She dwelt on her mounting unhappiness, her conviction that she was being watched and that her rooms had been searched. She seemed caught in a static world while the war raged around her. Her patriotic feelings for France clashed with her concern for her native Romania and her fear that it would side with Germany rather than the Western Allies. Cut off from her family by the war and by quarrels with Trajan over the family inheritance, she was plunged into an abyss of boredom, homesickness and guilt.

How have I been able to stay here so long? How has my destiny not allowed me to have another life? I feel strong and capable of being useful ... I cannot bear to pass my time in sighing and mulling over old ideas, in feeling so profoundly the misery of living in a milieu without affection and without warmth ... The Russians are in retreat ... Nothing heard from Romania. The English abandon their trenches. There are only the French who are admirable. There are only the French who resist and who would rather die than surrender. ${ }^{23}$

In a world devoted to the drama of war, Pascal felt crushed by inaction. Yet to speak of idleness is deceptive. She was fully engaged in her hospital work, visited patients in Clermont when their own doctor fled the region, an initiative for which she narrowly escaped official censure, and wrote numerous articles for the press. ${ }^{24}$ But she felt the war dramatized women's exclusion from meaningful action. Confinement to life in a provincial asylum came to seem increasingly unbearable. On 9 June 1915, sounding a Bovaryesque note, she made this despairing entry:

I suffocate here. I must leave. I want to live in Paris that home of solidarity, that nest of generosity. Here, egoism and avarice crush me. I continually have heart pangs and experience moral and physical weakness. I feel 


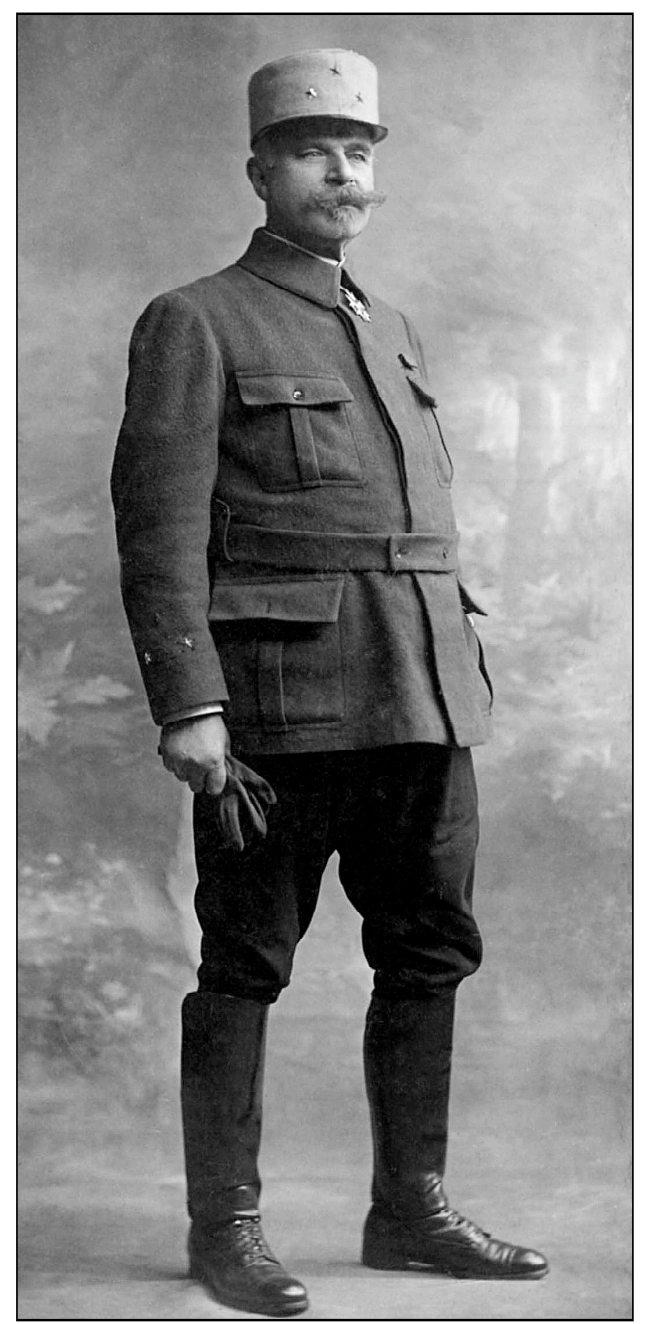

FIG. 2. General Mengin, c. 1914 (source: PRFP) enfeebled and diminished. Time passes in an identical state of lifelessness. $^{25}$

Yet shortly after, in the summer or early autumn of 1915, this comment appears: 'I had a discussion today with an interesting man, though like all intelligent men, he has his prejudices.'26

This entry was the first of a series of reported discussions on politics and army strategy with General Justin Mengin, Commander of the 6th Army Brigade, who had been quartered at Clermont de l'Oise in the Fitz-James Château, adjacent to the hospital. Mengin, ebullient, charming and intelligent, was the son of a schoolteacher. He had early shown intellectual promise, winning a place, first at the Lycée Charlemagne in Paris and then at the prestigious École Polytechnique where he graduated in 1876. Mengin was 59 years old when he met Mlle la Doctoresse Pascal. Photographs taken in the war years show a robust man with the Clemenceau moustaches of the day; see Fig. 2. He had a successful career behind him, having risen steadily through the ranks. He served in the Artillery and was attached to the General Staff. ${ }^{27} \mathrm{He}$ was a good example of the Third

Republic's commitment to meritocracy.

General Mengin was also a married man. It is possible that he first encountered Pascal when he came to consult her about his wife, Marie Gabrielle Nicolas Mengin, who four years later, in 1920, would be interned in the asylum of Evreux and who may already have been suffering from mental illness. ${ }^{28}$ Pascal was 38 when she and Justin Mengin met, desperately lonely, socially isolated, anguished about the progress of the war and the fate of her family in Romania. Their love affair must have astonished them both. Was their marriage ever a possibility? Under French law Mengin could not 


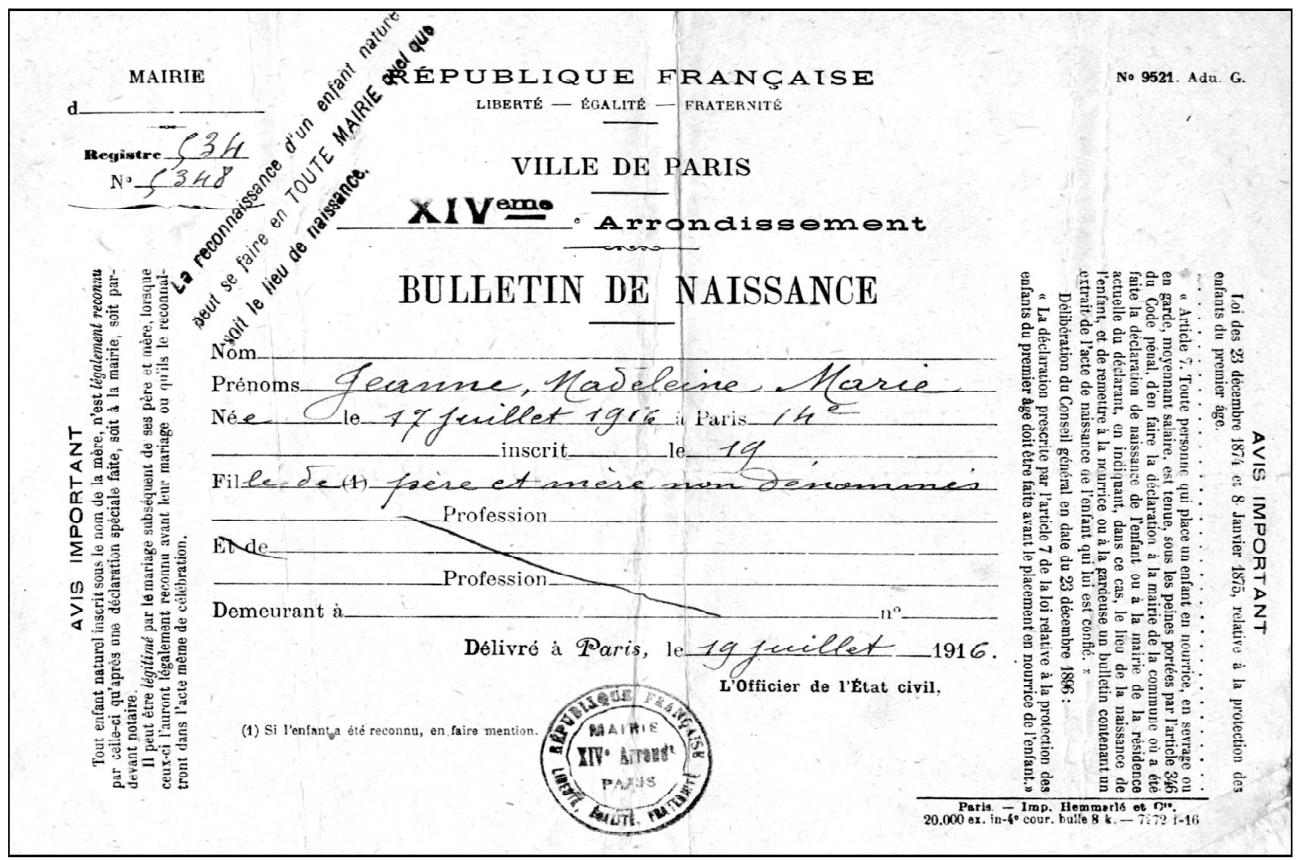

FIG. 3. Jeanne Pascal's birth certificate, 1916 (source: PRFP)

divorce if his wife was detained in a mental hospital. ${ }^{29}$ We know she was interned in 1920, but may have resided in another hospital previously. ${ }^{30}$ Commenting on a similar case of one of her patients, Pascal would remark: 'I have seen many husbands file through my office who want to cut the leash; it can't be done. ${ }^{31}$ Mengin may have been one of those husbands.

Our only clues as to subsequent events come from the official asylum dossier (Clermont DACP). Pascal must have realized she was pregnant sometime in November 1915. Her pregnancy constituted a major professional and personal crisis, yet she deeply desired a child. But with her whole career at risk, secrecy was imperative. She obtained leave on 1 April 1916 'for reasons of health', later explained in her dossier as 'a surgical operation', assumed to be of a gynaecological nature ${ }^{32}$ With the assistance of a loyal friend, Jeanne Streicher, Pascal booked into a Paris nursing home. ${ }^{33}$ On 22 April, with her leave nearly expired but the baby not due until July, Pascal applied for a further three months' leave, sending medical certificates as justification. She finally returned to her post at Clermont on 16 August, exactly one month after the birth of her daughter, Jeanne, on 17 July 1916. The birth certificate (Fig. 3) simply records: 'daughter of unnamed father and mother'. There is no surname; $;^{34}$ when formally adopted in 1924 , the child was given her mother's family name. 
Unwilling to remain at Clermont where she had been so unhappy, Pascal effected a temporary transfer from Clermont to la Maison Nationale de Santé at Saint Maurice, Charenton. Having initially put her daughter in a nursery, she now fostered the baby, listing the General and Jeanne Streicher as co-guardians. Here, closer to Paris, she was much happier. This position paved the way for her next posting to the asylum at Prémontré, where she was appointed médecin-chef on 17 January 1920, the first woman to achieve that position in a psychiatric hospital in France.

\section{Post-war career}

Prémontré was a former monastery, situated some three kilometres on the German side of the Hindenburg line and nearly destroyed during the 1914-18 war. The patients, deprived of doctors, had remained in the care of sisters of charity. Of 1300 patients, 539 died of malnutrition or typhoid in the first year of the war. By 1918 the splendid buildings of the Prémontré order, dating from the eighteenth century, were in ruins (Charpentier, 1921). Even today, the facades remain full of shell holes. Reconstruction began in 1919, but when Pascal arrived in January 1920, with a four-year-old child, she found a chaotic situation; the buildings were in ruins and patients were wandering about aimlessly. Her brother, Trajan, who was in the Romanian legation negotiating the Versailles Treaty, helped with her move - evidence of a family rapprochement at this period. Little Jeanne was 'explained' to her brother and sister-in-law as a fostered war orphan. The official Prémontré dossier makes no mention of Pascal's child, a solitary clue being in the inventory of Pascal's effects that includes a child's highchair. General Mengin, now retired, was also in evidence and enjoyed friendly relations with the director. ${ }^{35}$ However, the hospital, staffed by nuns, resisted Pascal's efforts to reform punitive asylum practices. ${ }^{36}$ She commented acidly: 'I upset firmly held ideas, beliefs and habits. In this closed-off milieu, the fresh air of a living civilization can only penetrate with great difficulty. ${ }^{37}$ Whether for this reason, or the strain of living in deplorable conditions with a young child, Pascal fell ill with a combination of nervous and rheumatic symptoms. She served only $1^{1 / 2}$ years of her 2-year appointment at Prémontré before successfully applying to move to Châlons-sur-Marne (Prémontré DACP).

At Châlons, Pascal found a more compatible milieu. Assisted in her move by General Mengin, she was given decent accommodation and was able to devote herself creatively to her work. She almost immediately began to implement a project she had been contemplating since Clermont: the creation of outpatient services for handicapped children (service ouvert pour enfants anormaux). Pascal submitted her plans to the Commission de Surveillance on 21 June 1922, which approved them. ${ }^{38}$ She then went on to found, on 18 July 1923, one of the first Instituts Médico-Pédagogiques in France. She argued that 'les enfants anormaux', like all children, should be 
taught by trained teachers. She wanted her institute to serve the children of the Marne region in order to avoid separation from their families. She travelled all over France to find those children formerly sent away from the locality. The Minister for Health congratulated her for having organized, 'on principles of the greatest humanity, a school for handicapped children, which served as a model for other new schools in France' ${ }^{39}$ Pascal's work was also highly praised by Georges Heuyer, an important reformer of education for children with learning difficulties (Gaillac, 1971; Heuyer, 1914).

The subsequent history of Pascal's groundbreaking initiative was less fortunate. The combination of outpatient services for children and learning opportunities that she had instituted at Châlons began to be dismantled soon after her departure in 1926, when she moved to the Paris region. In 1930 Georges Heuyer wrote to Brisac, a former prefect of the Marne, lamenting the decline of the Institut Médico-pédagogique at Châlons, 'which had rapidly gained a legitimate fame, for it responded to an evident need and gave excellent results. ${ }^{40}$ For her part, Pascal protested vigorously about the Institute's new policy of only taking children with moderate learning difficulties and banishing those with more severe difficulties to other departments. 'The Marne could not look after them, find them a little place in the sun of their family home. It is heart-breaking, painful, distressing. ${ }^{41}$

Meanwhile, little Jeanne Pascal continued to thrive. General Mengin, a frequent visitor, was proud of his bright and energetic 'god-child'. In 1924 Pascal was able formally to adopt her daughter, a move made possible in 1923 by a change in the law that previously allowed only adult adoption, the great number of war orphans having made the adoption of young children a pressing issue. Pascal seems to have acted speedily to ensure her child's legal status and to give her a name. But there was still no question of either parent recognizing their daughter as their own.

Pascal was the first woman to succeed in the competitive examination for médecin-chef of the Seine Department (an additional hurdle for those seeking posts near Paris) and was appointed Medical Director at the Asile de Moisselles in February 1926, a relatively small hospital (332 inmates). Its patients were women, many of them elderly, and children. The death-rate was high: in 1926, 11 women and 43 children died. From Pascal's official report, it is evident that she was deeply disturbed by the dreadful facilities, particularly for the children, and the toll taken by preventable illnesses. ${ }^{42}$ Tuberculosis, typhoid and the ravages of hereditary syphilis as well as common childhood diseases (mumps and whooping cough) all thrived as a result of poor hygiene and the impossibility of isolating patients:

I emphasize the regrettable defects in this service: crowding and insufficient hydrotherapy, which facilitate the growth and propagation of germs. For more than 100 incontinent children, we have not had a single bath; hot water is lacking everywhere. We have been obliged to organize regular baths for the children in the women's bathing areas. ${ }^{43}$ 
When she attempted to put the educational schemes undertaken at Châlons in place at Moisselles, she ran into administrative intransigence based on a desire to save money and on the view that only 'educable' children should receive instruction (Duché Didier, 1990).

As she did in all her further annual reports, Pascal was at pains to praise the nursing staff's efforts:

I am happy to be able to make mention of the devotion of nurses and assistants; they have fulfilled their posts with courage, patience and vigilance, and it is thanks to their exceptional qualities that we have been able to limit the three serious epidemics that reigned during six months in the children's ward. ${ }^{44}$

Pascal's forefronting of the contribution of female nursing staff relates to her broadly feminist concerns. Although she is always referred to as the first woman in French psychiatry, the reality was that psychiatric hospitals had always been largely staffed by women, often poorly trained and badly paid. Women were the backbone of the system, though not in positions of authority. Pascal never forgot that the gruelling day-to-day care of her patients depended on an army of mostly forgotten women. They in turn were devoted to her. ${ }^{45}$

Appointments to psychiatric hospitals in the Seine region were much sought after. In 1928, two posts became available, one at Perray Vaucluse, to the south of Paris, and one at Maison Blanche in an eastern suburb. Pascal, eager to work in a larger, more prestigious hospital and to be closer to Paris for the sake of Jeanne's schooling, applied for and was appointed to the latter. In her nine years at Maison Blanche while actively engaged in research, hospital administration and patient care, she closely supervised her daughter's education. She was determined that Jeanne, disadvantaged by her birth, would have all the intellectual preparation necessary for a successful life. But the shadow of illness darkened Pascal's final years. At the moment that her professional position was secured as médecin chef at Maison Blanche, she was diagnosed with breast cancer; she underwent a mastectomy in 1928 and could never have been free of the fear of recurrence thereafter.

\section{Later research and publications}

From 1926 to 1937, Pascal continued with an ambitious programme of research and publication. These works can be divided into two phases: those dealing with shock therapies and her more psychoanalytically-based research (Pascal, 1935). From a lay perspective, works such as Le Traitement des maladies mentales par les chocs (Pascal and Davesne, 1926) seem horrifying, by revealing the nakedly experimental nature of the treatments (Pascal, Vié and Agasse, 1929). Conversely, Pascal's genial clinical account of a woman patient 'cured by joy', undergoing a spontaneous amelioration of her condition, suggested the limits of psychiatric/medical intervention (Pascal and Royer, 
1935). Finally in Chagrins d'amour et psychoses (Pascal, 1935), she focused on the emotions, examining the ravages of a broken heart.

Chagrins d'amour is anything but a sentimental work. Its continuing relevance lies in Pascal's beautifully written cultural history of mental suffering in love, a condition that psychiatry as a science, she argued, had tended to avoid. Her wide, indeed omnivorous, reading permitted Pascal to range across centuries and disciplines and, among other things, to come to a nuanced, but by no means uncritical, appreciation of Freud. Her interest in Freud and his school dated from before the war. Pascal praised his insights, though dissenting from what she saw as his reductionism and pan-sexualism. She recognized that the 'talking cure' was not an option for most psychiatric patients. Nevertheless, Freud had shown the way to a semiotics that could prove the key to understanding some of the most intractable mental illnesses. I $\mathrm{n}$ opposition to Freud, she argued that disappointed love, when it precipitated mental breakdown, was not merely a recreation of an Oedipal moment. Like Bergson, whom she admired, she believed that we live and develop in real time. Life was more than the re-enactment of a primary experience. She linked Freud with the seventeenth-century philosopher, Blaise Pascal (no relation):

Freud had the great merit of recreating Pascal's man, he of the sick heart, the weak soul, man a slave of his instincts and lacking reason. By following the traces of love beyond the genital, he discovered the true value of the sexual aetiology of mental and physical illnesses ... He merits our admiration. (Pascal, 1935: 58; original emphasis)

Without being reductionist, one can suggest that in Chagrins d'amour Pascal went beyond the analysis of case-histories. She seems to have found her own voice and to have felt free to bring her philosophical and literary interests, and to some extent her personal experience, to bear on her patients' illnesses. Yet if Pascal's own perspective on disappointed love informs this text, it is, nonetheless, a surprisingly optimistic work. Love can take more than one form and can be fruitfully surmounted or sublimated. In her case, maternal love was as - if not more - profound than sexual love, which brings us back to General Mengin and Jeanne Pascal.

\section{Family matters}

Throughout Jeanne's childhood, the General was a frequent family visitor. He accompanied Constance and Jeanne on holiday and in Paris often fetched Jeanne from school (she attended the Collège Sévigné from the age of nine to seventeen). He provided some financial support. Jeanne's parents maintained a distant though cordial relationship, always addressing each other by the formal 'vous':

The General, as he was called, or Parrain (godfather), as I had been taught to call him, is associated with my first childhood memories at 


\begin{abstract}
Charenton [Saint Maurice, 1917-19]. No doubt his role was defined by agreement with both my parents. They had no life in common. My mother lived near to or in the asylum; Parrain lodged with Colonel Baron Reille, his former Chef d'État Major. Neither the one nor the other informed their own families of the existence of their daughter. But it was quietly understood, that Parrain would help me in life. ${ }^{46}$
\end{abstract}

Shortly after Jeanne's fourteenth birthday (17 July 1930), her mother informed her that her adored 'Parrain' was in fact her father. The central but unspoken message that emerged from her mother's communiqué, however, was that her paternity was a secret that must never be revealed. When (26 July) the General wrote affectionate letters to Jeanne and Constance admitting paternity and pledging to do everything he could for Jeanne's welfare, he did not sign his letters. For Pascal, this sentimentality mixed with caution was characteristic of the man. She hoped that he would have formally recognized his daughter, but he did not. After the General's death, two years later, she wrote to Jeanne: 'He did not wish to do his duty towards you. He could have done so. Peace to his ashes, but a truce, too, to lies. ${ }^{47}$

Madame Jeanne Rees's conclusions about her parents show her appreciation of them as actors in the social history of their time. The General, she said, had a boundless admiration for her mother and was devoted to her. But he was the prisoner of his petit bourgeois background and of the social milieu to which he had raised himself in his career. Constance Pascal had loved and admired him in 1915, but could not pardon him for not having sought to legitimize their daughter. During the General's last illness in 1932, Jeanne visited him daily in hospital, passing in the corridor elegantly dressed society ladies, strangers to her, who were part of her father's other world. At his funeral at Val de Grâce, attended by the great and the good, Constance and Jeanne Pascal were snubbed by Baron Reille, who, as a devout Catholic, once referred to Jeanne as la fille du péché (the daughter of sin). ${ }^{48}$ Pascal was haunted by the disadvantaged status that she and Mengin had conferred on their daughter. France - not the France of Bohemia, but of the professional middle classes - was not a country where illegitimacy was easily overlooked. Pascal knew that her distinguished public reputation would never recover from the revelation that she had born a child out of wedlock. More importantly, she knew her daughter's chances in life were compromised.

For a woman of Pascal's integrity and forthrightness, this regime of lies and deception embittered her life, especially towards the end. The most revealing document relating to the whole social/legal issue of legitimacy is an unpublished film-script she wrote about 1937 entitled 'La Goutte de Sang' (The Drop of Blood). ${ }^{49}$ Set in a research laboratory, the story concerns an eminent biologist searching for an infallible paternity test. When his laboratory assistant, a young woman Christiane Viot, finds the solution, the biologist believes that they have solved a social, not merely a scientific problem: 'Children will be sacred, they will able to have their rights by 
showing the proof of blood legitimacy. Faced with this proof, who will dare to renounce his child? ${ }^{50}$

Here was the imagined answer to General Mengin's pusillanimity. In a country where women still had few civil rights, a child's legal identity was vested in the father. Proof of paternity was in a sense proof of existence. However, as the drama unfolds, other points of view emerge. One researcher doubts that anything will change; his professor's faith in social transformation through science will run up against masculine intransigence: 'He doesn't take into account men's cowardice ... and that since the world is as it is, the male governs everything. ${ }^{51}$ Christiane (the unacknowledged and unknown daughter of the eminent biologist) becomes disillusioned with the social results of her discovery. She attacks the biologist for his success in implementing systems to track down errant fathers:

The new man that you have created is ridiculous, abnormal, pathetic. $\mathrm{He}$ is perpetually hounded. Marriage is no more than a prison where the parents are obliged to obey the law of blood ties ... even if they detest each other; they live like chained convicts with their unhappy children. Ah! Science, don't you see, can't create morality; it lacks pity, it only has one aim: cold truth and glacial justice. It dries up the generous impulses of nature ... Its rigid formulas are inapplicable to morality. ${ }^{52}$

Pascal, in imagining a solution to the problem of acknowledging paternity, concluded that moral dilemmas will always be with us. The religion of science to which she had dedicated her life, was insufficient. Her protagonist affirms a virtually Kantian ethical imperative in the declaration: 'No one is allowed to live without some constraint. No one is moral enough to merit complete liberty. ${ }^{53}$

\section{Conclusion}

Pascal was driven by an ethical passion devoid of any religious basis. Although she sought truth through science, she looked increasingly to philosophy, literature and social action for meaning. Probably to this end, she subscribed to l'Union pour la vérité, a journal of the left, concerned with the restoration of moral values and workers' education (Chaubet, 2000). Her social concerns were reflected in her pioneering work in the education of children with severe learning difficulties which deserves far more recognition than it has received. Looking back over her career, she was justifiably proud of her role in advancing the cause of women in psychiatry and in improvements that she had championed in psychiatric care. Her daughter's academic success delighted her, though she did not live to see her pass her agrégation, or her marriage to the young Welshman who in 1930 had been employed to tutor Jeanne in English. In the last year of her life, Pascal was still working on a major new project, a monograph to be entitled La Démence précoce de Morel- 
Kraepelin et le problème de la schizophrénie. ${ }^{54}$ She died of cancer on 21 December 1937, at her house at Maison Blanche, alone except for her daughter and medical attendants. Stoical in the face of death, she had insisted on the simplest of funerals and wanted no commemoration in the psychiatric press. Dr Jacques Vié, who wrote her obituary, provided the only official notice of her death (Vié, 1938).

Pascal's work in psychiatry is notable for its evolution and its lack of dogmatism. Her empathy with her patients arose from clinical observation, from her own emotional scars and her wide cultural perspective:

The person wounded by love is someone with a hyper-affective memory; his recall of painful emotions is over-developed. 'He suffers because he remembers' (Beethoven). Time, as he lives it painfully, is continually regained. This constitutes the essential framework of the sorrows of love. To the distressing burden of the past is added the harrowing burden of the present. Proust rediscovered his lost Eden, whereas the person wounded by love keeps rehearsing his despair, and allows himself to be obsessed by disgust or hatred. (Pascal, 1935: 159)

It is not an ad feminam argument to suggest that Pascal's own deception in love contributed to her interest in and concern for those 'blessées d'amour' who, unlike herself, had lacked the intellectual and emotional strength to overcome their despair. The fact that the majority of clinical examples in Chagrins d'amour are women points to her conviction that many of the emotional disasters in life fell disproportionately on women; they were the distorted mirror of social realities underpinned by masculine power structures.

Constance Pascal's virtual disappearance from the historical record until recently was partly self-imposed and partly due to newer fashions in psychiatry that eclipsed her work, especially on dementia praecox. Feminist historians have also failed to give her the attention she merited, because of the technical nature of her writing and because it was wrongly assumed that her much extolled feminine persona precluded a feminist commitment. Her gushing journalistic admirers, focusing on her personal appearance, served her badly with subsequent scholars, as in this extract (Anon., 1905):

She is a foreigner, like many women doctors: a Romanian. Her great black eyes bring to mind her country of origin ... She always dresses in black, which suits her. As for her hair, a carefully arranged chignon and two neat coils over the temples, demonstrate that a certain 'coquetry' and aesthetic sense are not incompatible with science.

It may be thought that Pascal paid a heavy price for her professional distinction in terms of the burdens it placed on her. But she succeeded in balancing her two worlds: in maintaining her economic independence and in raising her daughter to compete in the hot-house of French intellectual life. 
She was not a victim. When faced with certain death, she expressed anguish, but also demonstrated great courage. She kept her secret to the end. The product of a Francophone, pan-European culture as it existed before World War I, Constance Pascal was a remarkable example of those gifted and dedicated new women determined to prove their absolute competence in a man's world.

\section{Acknowledgements}

I wish to thank Anglia Polytechnic University, the British Academy and The Wellcome Trust for grants in support of this project. I am most grateful to Mme Jeanne Rees and Dr Margaret Rees for access to the Pascal/Rees Family Papers.

\section{Notes}

$\mathrm{CP}=$ Constance Pascal; other abreviations are listed in References (a) on p. 180.

1. 'Aucune trace de relation sentimentale n'a été retrouvée.' (Barbier, 1997: 44).

2. She was born on 25 August 1877 in Pitesti, Wallachia, Roumania, and named Constanza Pascal, changing her name to Constance, when naturalized as a French citizen on 2 March 1907 (Bulletin des Lois de la République Française, XIIe série, Partie Supplémentaire, Tome LXXIV, Bulletin 4137, 3379; AVP).

3. Letter from Mathilde Salomon to CP, 4 Feb. 1909. All translations from the French are my own.

4. Letter from CP to Trajan Pascal, undated, c. 1910-11.

5. Letter from CP to Marie Pascal, undated, c. 1912.

6. In the initial cohort of four women, only one, Mme Brès, was French. The foreign intake continued to be high even after the turn of the century. See Gordon, 1990: 28.

7. For the importance of domestic ideology in France, see: Grogan, 1992; McMillan 2000; Roberts, 1994; Witz, 1992.

8. CP, 'Réflexions sur le concours du médicat des asiles de 1933', unpublished MS (PRFP).

9. Dr Edouard Toulouse, 'La femme et les functions publiques', Dossier Madeleine Pelletier (BMD).

10. CP to Trajan Pascal, c. 1911-12.

11. Pascal's naturalization (1907) was a requirement before she could sit her psychiatric examinations in 1908. For legislation relating to naturalization in France, see Adreani, 1896.

12. Letter from CP to M. Daumezon, Médecin des hôpitaux psychiatriques, undated, $c$. 1930.

13. To gain French naturalization, a 10-year period of good behaviour was required; overt feminist agitation would not have qualified as good behaviour. Feminists were not only ridiculed in the press, they were considered subversive and were routinely the object of police surveillance. Gordon, 1990: 5, 83; 112-13.

14. Undated article, possibly from La Fronde, courtesy of the Bibliothèque Marguerite Durand.

15. Dr Courbon, unpublished MS; courtesy of Dr Jacques Chazaud (PRFP). 'What happened to her' (Pelletier) was one of the silent tragedies of the inter-war years. Arrested on the charge of assisting in an abortion, she was judged incapable, having suffered a 
stroke, and was interned in the Asylum of Perray-Vaucluse where she died in 1939. Gordon, 1990: 221-32.

16. CP, unpublished War Journal (1914-18), II: 15 (PRFP).

17. Undated newspaper article, c. 1912 (Clermont DACP).

18. Letter from Professeur H. Baruk to Mme Jeanne Rees, 27 Oct. 1968.

19. Translations of Freud's work did not appear in France until 1922, with Jankelvitch's translations; see: Postel and Quétel, 1983; Turkle, 1979.

20. A letter from Emil Kraepelin to CP, 26 May 1909, demonstrates that she had informed him of her research and requested information on his latest theories. In his cordial reply, he invited her to join his clinical team.

21. In 1911 Pascal published a condensed version of her monograph on dementia praecox (Pascal, 1911a). My discussion is based on this text.

22. Pascal (1914-18), War Journal, I: 52 (PRFP).

23. Pascal (1914-18), War Journal, I: 30-32 (PRFP).

24. Over a 4-year period, from 1914-18, Pascal wrote bi-monthly articles on childcare for $L e$ Petit Echo de la Mode, a Catholic-owned periodical consecrated to the support of family values. For the growth of a bourgeois or petit bourgeois readership for women's magazines and their function in strengthening domestic ideology, see: Samra and Maignien, 1986: 16; Sullerot, 1966: 7-59.

25. Pascal (1914-18), War Journal, I: 46 (PRFP).

26. Pascal (1914-18), War Journal, I: 52 (PRFP).

27. Mengin was promoted to Lieutenant in 1878, Captain 1884, Squadron-Leader 1898, Lieutenant-Colonel 1904, Colonel 1907; a two-year posting in Algeria (beginning Feb. 1912) was followed by promotion to General of Brigade in May 1912 and General of Division 1914. Dossier Justin Mengin (AHMD).

28. Information supplied by the Bureau de la Gestion des Malades, Centre Hospitalier Spécialisé de Navarre, Evreux, 22 May 2003.

29. The law of 1884 which liberalized divorce in France, forbade it in cases of patients interned in asylums, a measure intended to protect the interest of the mentally ill; see Murat, 2001: 290-2.

30. It has yet not proved possible to disentangle the story of Mme Mengin further. Forty-six when she married Justin Mengin, they had co-habited for 20 years, unable to marry before, as Marie Nicholas lacked the private income required of officers' wives. See 'Le Mariage des Officiers', La Fronde, 28 December 1901 (BMD); also: Berger-Leuvrault, 1910: 1844; Croubois, 1987: 232-4; Serman, 1982: 145-83.

31. Letter from CP to Director, Prémontré, 25 Sept. 1921 (Prémontré DACP).

32. Letters from the Prefect of the Oise to the Director of the Asile d'Aliénés, Clermont, 1 April 1916, and from the Director to the Prefect, Oct. 1916 (Clermont DACP).

33. Maison de Santé, 219 rue Vercingétorix, Paris XIVe (Clermont DACP). Pascal had met Jeanne Streicher as a student in Paris. Streicher was one of the first women to become 'agrégée' at the École Normale de Sèvres and taught there. Though disapproving of what she considered Pascal's 'lapse', she remained loyal in the crisis of her pregnancy, was godmother to her child and Pascal's most intimate friend until the latter's death (Mme Jeanne Rees, unpublished 'Recollections of Constance Pascal', 2001).

34. Bulletin de Naissance Ville de Paris XIVème Arrondissement, Jeanne Madeleine Marie, 17 juillet 1916 (PRFP).

35. Letter from General Mengin to Director Prémontré, 14 Feb. 1922 (Prémontré DACP).

36. In a report by Dr A. Marie on the asylums of western France, he accused the nuns of lacking any understanding of the principles which ought to underpin the treatment of the mentally ill (La Fronde, 20/01/1901; BMD). Twenty years later Pascal had similar 
difficulties in reforming asylum practice, when run by nuns, partly because authority over the nursing sisters was vested in their mother superior, not in the clinical medical staff.

37. CP to the Director, Prémontré, 30 Nov. 1921 (Prémontré DACP).

38. Asile Départemental d'Aliénés de Châlons-sur-Marne, Extrait du Registre des Déliberations de la Commission de surveillance, 15 avril 1922 (AM). On the movement to create open psychiatric services in France, see Thomas, 2004: 131-53. Dr Edouard Toulouse, who pioneered out-patient services at St Anne, asked Pascal for her advice on organizing 'dispensaires psychiatriques' in the Seine-et-Oise and Seine-et-Marne departments. Letter from CP to Docteur Toulose, 27 May 1937 (PRFP).

39. CP letter to the Prefect of the Département de la Seine, 4 May 1930 (AM).

40. Letter to M. Brisac from Dr Georges Heuyer, 16 April 1930 (AM).

41. CP letter to the Director, Asile de Châlons-sur-Marne, 4 Mai 1930 (AM).

42. Asile de Moisselles, Année 1926, Rapport, de Mlle le Dr C. Pascal, Médecin Directeur (Moisselles DACP).

43. Ibid. (1926: 151).

44. Ibid.

45. Letters and poems (1926) to CP from staff at Châlons (PRFP).

46. Mme Jeanne Rees, unpublished 'Recollections of Constance Pascal', 2002.

47. CP to Jeanne Pascal, note attached to letters of 26 Aug. 1930 from General Justin Mengin.

48. Mme Jeanne Rees, unpublished 'Recollections of Constance Pascal', 2002.

49. Letter from Jean Painlevé, Director of Institut de cinématographie scientifique, to CP, 15 April 1937, expressing interest in her screen-play.

50. La Goutte de Sang I: 11 (PRFP).

51. Goutte I: 2 (PRFP).

52. Goutte III: 18 (PRFP).

53. Goutte III: 20 (PRFP).

54. CP to unknown Spanish correspondent 29 Jan. 1937.

\section{References}

(a) Archival sources

AHMD = Archives Historiques de la Ministère de Défense, Armée de la Terre, Vincennes.

$\mathrm{AM}=$ Archives de la Marne.

AVP $=$ Archives de la Ville de Paris.

$\mathrm{BMD}=$ Bibliothèque Marguerite Durand.

Clermont DACP = Centre Hospitalier de Clermont de l'Oise: Dossier Administratif, Constance Pascal.

Maison Blanche DACP = Centre Hospitalier de Maison Blanche: Dossier Administratif, Constance Pascal.

Moisselles DACP = Centre Hospitalier de Moisselles: Dossier Administratif, Constance Pascal.

Prémontré DACP = Centre Hospitalier de Prémontré: Dossier Administratif, Constance Pascal.

PRFP = Pascal/Rees Family Papers (see Acknowledgements on p. 178). 


\section{(b) Publications}

Adreani, A. (1896) La Condition des étrangers en France et la législation sur la nationalité française (lois des 26 juin, 1889, 22 juillet et 8 août 1893) (Paris: Librairie Guillaumin et Cie).

Anonymous (1905) Femmes internes, hôpitaux et asiles. La Vie heureuse, (Feb.)

Barbier, Jean-Michel (1997) La vie et l'oeuvre de Constance Pascal (1877-1937). Thèse pour le Doctorat en Médecine (Diplôme d'Etat), Université de Picardie, Faculté de Médicine d'Amiens.

Barbier, Jean-Michel, Serra, Gérard and Loas, Gwenolé (1999) Constance Pascal: pioneer of French psychiatry. History of Psychiatry, 10, 425-37.

Basch, Victor (1936) Schumann: A Life of Suffering, translated by C. A. Phillips (New York: Alfred A. Knopf); originally published in French in 1928.

Becker, Annette (1998) Oubliés de la Grande Guerre (Paris: Editions Noêsis).

Berger-Leuvrault (1910) Dictionnaire militaire (Paris).

Blancpain, Marc (1983) La Vie quotidienne dans la France du Nord sous les occupations, 1814-1944 (Paris: Hachette).

Bleuler, Eugen (1911) Dementia Praecox: oder Gruppe der Schizophrenien (Leipzig: F. Deuticke).

Charpentier, Joseph (1921) Un asile martyr, prémontré pendant la guerre. L'Informateur des Aliénistes et des Neurologistes, 16 (1), 154-9.

Chaubet, François (2000) Paul Desjardins et les décades de Pontigny (Paris: Presses Universitaires du Septentrion).

Chazaud, Jacques (2001) Constance Pascal, première femme aliéniste en France. Histoire des Sciences Médicales, 35 (1), 85-90.

Croubois, Claude (1987) L'Officier français des origines à nos jours (Saint-Jean-d'Angely: Editions Bordessoules).

Duché Didier, Jacques (1990) Histoire de la psychiatrie de l'enfant (Paris: Presses Universitaires de France).

Duroselle, J. B. (1995) La Grande Guerre des français, l'incompréhensible: 1914-1918 (Paris: Perrin).

Foucault, Michel (1961) La Folie et la déraison: histoire de la folie à l'âge classique (Paris: Plon).

Gaillac, Henri (1971) Les Maisons de correction 1830-1945 (Paris: Editons Cujas).

Gaines, Ruthe (1918) A Village in Picardie (New York: E. P. Dutton).

Goldstein, Jan (1987) Console and Classify: The French Psychiatric Profession in the Nineteenth Century (Cambridge: Cambridge University Press).

Gordon, Felicia (1990) The Integral Feminist: Madeleine Pelletier, 1874-1939 (Minneapolis: University of Minnesota Press).

Grogan, Susan K. (1992) French Socialism and Sexual Difference: Women and the New Society 1803-44 (Basingstoke: Macmillan).

Heuyer, Georges (1914) Enfants anormaux et déliquents juvéniles (Paris: G. Seinheil).

Macintyre, Ben (2001) A Foreign Field (London: Harper Collins).

Margadant, Jo Burr (1990) Madame le Professeur: Women Educators in the Third Republic (Princeton: Princeton University Press).

McMillan, James F. (2000) France and Women 1789-1914: Gender, Society and Politics (London and New York: Routledge).

McPhail, Helen (1999) The Long Silence: Civilian Life Under the German Occupation of Northern France, 1914-1918 (London: I. B. Tauris).

Murat, Laure (2001) La Maison du Docteur Blanche (Paris: Hachette).

Ostwald, Peter (1985) Schumann: Music and Madness (London: Victor Gollancz).

Pascal, Constance (1905) Formes atypiques de la paralysie générale: prédominances régionales des lésions dans les méningo-encéphalites diffuses (Paris: Thèse d'ètat). 
Pascal, Constance (1906a) La Loi roumaine sur les aliénés: traduction et réflexions. Fournal de Médecine légale psychiatrique et d'anthropologie criminelle, 1, 204-13.

Pascal, Constance (1906b) Formes prodromiques dépressives de la démence précoce. Informateur des Aliénistes et des Neurologistes, 1, 186-8.

Pascal, Constance (1906c) Les ictus dans la démence précoce. Informateur des Aliénistes et des Neurologistes, 2, 139-44.

Pascal, Constance $(1906 d)$ Le sourire et le rire dans la démence précoce. Fournal de Psychologie, 6, 392-407.

Pascal, Constance (1907a) Pseudo-neurasthénie prodromique de la démence précoce. La Presse médicale, 1, 42-4.

Pascal, Constance (1907b) Les remissions dans la démence précoce. Revue de Psychiatrie, 2, $147-61$.

Pascal, Constance (1907c) Formes mélancoliques dans la démence précoce. Archives de Neurologie, 2, 273-93.

Pascal, Constance (1908) Les maladies mentales de Robert Schumann (génie et démence). Fournal de Psychologie Normale et Pathologique, 5, 98-130.

Pascal, Constance (1911a) La démence précoce: étude clinique et médico-légale. Revue de Médecine, 31, 304-33.

Pascal, Constance (1911b) La Démence précoce (Paris: Alcan).

Pascal, Constance (1935) Chagrins d'amour et psychoses (Paris: l'Harmattan); reprinted, 2000.

Pascal, Constance and Davesne, J. (1926) Le Traitement des maladies mentales par les chocs (Paris : Masson).

Pascal, Constance and Royer, J. (1935) La joie qui guérit, L'Hygiène Mentale, 2, 157-65.

Pascal, C., Vié, J. and Agasse, P. (1929) Guérison rapide d'une influencée catatonique à la suite de vaccination anti-typhique. L'Encéphale, 316-19.

Porter, Roy (2002) Madness: A Brief History (Oxford: Oxford University Press).

Postel, Jacques and Quétel, Claude (1983) Nouvelle histoire de la psychiatrie (Paris: Dunod).

Quétel, Claude (1992) The History of Syphilis (Cambridge: Polity Press).

Rees, Jeanne (2001) À propos de Constance Pascal, première femme aliéniste en France. L'Information Psychiatrique, 2, 173-83.

Roberts, Mary Louise (1994) Civilisation Without Sexes: Reconstructing Gender in Post-War France 1917-1927 (Chicago and London: University of Chicago Press).

Roberts, Mary Louise (2002) Disruptive Acts: The New Woman in Fin-de-siècle France (Chicago and London: University of Chicago Press).

Samra, Martine Bonvoisin and Maignien, Michèle (1986) La Presse féminine (Paris: Presses Universitaires de France).

Scull, Andrew (1979) Museums of Madness: The Social Organisation of Insanity in NineteenthCentury England (London: Allen Lane).

Serman, William (1982) Officiers français dans la nation 1814-1914 (Paris: Aubier-Mongaigne).

Sowerwine, Charles (1988) Madeleine Pelletier (1874-1939), femme, médecin, militante. L'Information Psychiatrique, 9, 1189.

Stricker, Rémy (1984) Robert Schumann: le musicien et la folie (Paris: Gallimard).

Sullerot, Evelyne (1966) La Presse féminine française (Paris: Armand Colin).

Taylor, Robert (1982) Robert Schumann: His Life and Work (London: Granada).

Teillet, Claude (1983) Le Centre Hospitalier Spécialisé de Clermont de l'Oise de 1790 à nos jours. Mémoires de la Société Archéologique et Historique de Clermont en Beauvaisis, 35.

Thomas, Gregory M. (2004) Open psychiatric services in interwar France. History of Psychiatry, 15 (2), 131-53.

Turkle, Sherry (1979) Psychoanalytic Politics: Freud's French Revolution (London: Deutsch).

Vié, J. (1938) Mademoiselle C. Pascal (1877-1937). La Presse Médicale, (Jan.), 150.

Witz, Anne (1992) Professions and Patriarchy (London: Routledge). 